\title{
Study on Chinese City Regulations Concerned with Urban Street Profile Characteristics
}

\section{Caixia Gao}

Ningxia University, Yinchuan, Ningxia, 750021

Keywords: Urban street profile characteristics; urban regulations; relevance; mandatory regulations; guiding regulations

\begin{abstract}
The urban street profile is a product of different social levels, especially from the economic development dynamics and the influence of relevant city regulations. This study focuses on relevant city regulations. Taking Nanjing as an example, it clarifies the key operational tools of the material composition and morphological characteristics of the urban street profile, sorts out the relevant provisions of the State, Jiangsu Province and Nanjing Municipality, graphically analyzes the main provisions of the provisions, and finally draws the relevant provisions of the regulations through the regulation of the proportion of land use, plot development strength, building location and other indicators related to the urban street level land layout type, plot, and morphological characteristics, such as the order of the building group and the continuity of the street interface. The research is of great significance for the revision of relevant urban regulations and the shaping of the quality of the urban material environment inhabited.
\end{abstract}

\section{Introduction}

The formation and development of urban street profile is influenced by many factors such as social behavior, policies and regulations, history, and context, while policies and regulations are operationally controlled for the formation of street profile. In China, according to the three levels of national, provincial and local cities, the urban regulations related to the urban material form include four categories: relevant laws, regulations, rules, norms and standards, such as the "People's Republic of China Urban and Rural Planning Law" and "Regulations on Urban and Rural Planning of Jiangsu Province, Regulations for the Implementation of Urban Planning Regulations of Nanjing, and Code for Fire Protection of Building Design. The original purpose of these regulations is to solve urban function and safety problems such as lighting, fire, earthquake, and traffic, and to achieve certain control effects [1], as passed in Article 24 of the Interim Provisions on the Administration of Nanjing Urban Construction Planning in 1987. To solve the problems of fire prevention and earthquake resistance and overcrowded traffic at the time, such as roads, highways, retreats, planned road red lines, and masonry walls height control [2].

However, since the 1980s, along with the rapid development of global urbanization, human beings are facing an urgent urban problem: the lack of a characteristic, dense and habitable urban environment [3], how to build a city, how to control the urban form To improve the quality of urban material environment has become a major problem solved by practitioners and experts and scholars. Therefore, the urban architectural form has evolved from the past only to the function to the pursuit of the coordinated development of image and function. Relevant regulations also face the transformation from guarantee function to control image. These regulations are facing the function and safety of the city. The more serious the urban street layout is disorderly, the street interface is not continuous, the spatial organization of the building group is disordered, etc. How to deal with relevant regulations, some local cities have initially compiled urban design guidelines, such as the guidelines for the preparation of urban design in Jiangsu Province. (2010) and so on. The academic community has also carried out research on the control of urban material form regulations, especially in countries such as Europe and the United States. The relevant documents suggest that urban construction regulations that mainly control and influence urban material form include direct related traditional zoning, form criteria, and social structure. The implicit rules of order, etc. [4], the 
traditional zoning system was originally to separate harmful functions, maintain good community and public space, improve health and safety, but the result of the use of zoning rules has led to the separation of urban population and Social problems such as functional separation, lack of public space, and urban sprawl. Since 1980, New Urbanism has proposed a form-based design criterion, which is a set of rules governing land use, land parcels, street interfaces, and building types. To shape the shape and appearance of the urban environment, and to provide design tools for the balance between urban diversity and order; China mainly has research on building regulation control, urban form control and shaping, such as Dingwowo research related The Path of Urban Regulations Controlling Urban Forms in Nanjing Strategy [3] 2, indicating that the relevant provisions of the land is divided by street blocks, building scale, building concessions and other controls, directly or indirectly, can affect the physical form of the city. Therefore, the study takes Nanjing as an example, sorts out the laws and regulations related to the characteristics of China's street profile and graphically analyzes its provisions, verifying the relationship between urban regulations and urban material forms, revising relevant city regulations, and shaping a livable city. Environmental quality is of great significance.

\section{The key elements of the urban material profile and the key operational tools for its feature control}

The urban street profile is an important part of the urban material form. It is a land-based unit surrounded by urban roads. It is connected to an urban street network. The interior includes plots, buildings, greening sites, facilities and other elements [5] [7]. The urban street profile is mainly represented by three scales of the layout of the street profile, the organizational order of the block building, and the continuity of the street interface. These morphological features are important aspects of urban material form management and control, and their corresponding attributes. It mainly includes: road environment around the street profile, street scale, land use property, land division number, land ownership boundary and land shape, building spacing, open site scale, building width along the street, building height, street width, The relationship between the relevant urban regulations and the urban morphological characteristics lies mainly in the changes of these characteristic attributes, which in turn is related to the development and change of the morphological characteristics of the street. Relevant regulations control the key tools of the urban street profile, mainly focusing on the material elements of the street profile and the regulations and attribute parameters of the relationship between the elements, such as street scale, land size, building height, building red line distance, construction Spacing, etc. [8].

\section{Combing and graphic analysis of Chinese urban laws related to urban street profile characteristics}

This study investigated 208 relevant regulations from three levels of the country, Jiangsu Province and Nanjing City, and found that there are few special regulatory documents for controlling the urban street profile in China, only in relevant urban planning and construction management regulations and related industry norms. Some of the provisions are covered. We have sorted out 119 legal documents mainly related to the material composition of the urban street profile and the connection regulations between the elements, about 6063 provisions, and using the mapping method according to the degree of correlation of the material elements involved in the street [9] ( Figure 1), which separates directly related, indirectly related and irrelevant provisions, and further classifies the relevant provisions into four categories: the first category is land use, building layout, plot indicators, and various types of illegal construction rewards and punishments. Directly related mandatory regulations; the second category is the direct guiding rules related to urban style and architectural style, street interface, building façade, greening and advertising, wall; the third category is urban planning and approval, land use rights transfer Indirect related mandatory regulations such as transfer contract planning and design conditions and relevant industry norms; the fourth category is indirect related guiding regulations such as protecting ecological environment, 
saving land, and renovating the city's appearance [10] [19]. The number of various provisions and their respective proportions are shown in Figure 2.

Judging from the carding results, there are still many regulations related to the urban street profile of the relevant provisions of the regulations, but the operability is mainly related to the direct and indirect related provisions of the first and third categories, which are directly related. The compulsory provisions only accounted for about $8.1 \%$, and the indirect related compulsory provisions accounted for $12.3 \%$. The number of these provisions is relatively small, and mainly includes the provincial planning and management technical regulations of Jiangsu Province and the Nanjing Urban Planning Implementation Rules. In the relevant laws and regulations of local cities, the advertisements, building facades and styles directly related to the urban street material form are mostly guided regulations, lacking quantitative indicators or hard rules for operability.

Mandatory regulations on the scope and scale of land use, the nature and compatibility of land use, basic control units, plot size and division, and the regulation of the use of land use such as land use classification and land use ratio, neighborhood scale and land division scale, and cities The morphological features such as the land type of the street profile are related. As shown in Figure 3 and Figure 4, we have illustrated Article 3.0.2 of the Code for Planning and Design of Urban Residential Areas (GB50180-93) and Article 6 of the Guidelines for the Preparation of Controlled Detailed Planning of Jiangsu Province (2012). According to the regulations on the classification of residential land and the proportion of land use, the scale of the block and the division of the land, it is preliminary judged from the theory that these regulations are closely related to the land form of the urban street level while effectively controlling the scale of land use, the scale of the block and the division of the land. .

In the relevant provisions of China's relevant laws and regulations, the land development intensity and the construction location are controlled by the hard-line regulations such as floor area ratio, building density, greening rate, building spacing, construction concession road red line and land boundary distance, but there is still a lack of Provisions for quantitative indicators such as land use properties, plot geometry and building relationships, and plot subdivision. The study illustrates the upper and lower limits of floor area ratio and building density in Articles 2.3 and 3.5 of the Technical Regulations for Urban Planning Management of Jiangsu Province (2012) (Fig. 5) and Articles 42-44 of the Regulations for Urban Planning Regulations of Nanjing (2007). According to the regulations of these regulations, it can be concluded theoretically that these regulations are closely related to the combination of building groups within the plot while controlling the strength of the land development and the location of the building. .

Directly related guiding regulations such as urban urban style, architectural style, advertisements, and fences are important aspects that affect the urban form of urban streets. However, due to the lack of quantifiable indicators, it is impossible to control the design scheme, and the control is not strong. . For example, Article 56 of the "Implementation Rules for Urban Planning Regulations of Nanjing" (2007) stipulates that "strictly controlling the construction of houses on both sides of the main roads of the city, if it is really necessary to construct, the facade of the building along the street should be handled well, and the urban landscape should not be hindered.” The purpose is to improve the street interface on both sides of the urban road, but there are problems: First, there is no limit to the definition of 'main road'. Is the 'main road' here determined according to the width range or based on traffic flow calculation? ? Secondly, 'handling the façade along the street' is a relatively ambiguous concept. It is not feasible to control the façade along the street only by strictly controlling the construction of houses on both sides of the road. According to the 2004 Nanjing Detailed Control Plan, 1195 hectares of public construction land is planned in the old city of Nanjing, including 447 hectares of commercial land and 759 hectares of land. If this is stipulated, both sides of the road will be used for commercial development. Far more than the current needs, it can be seen that Article 56 of the Rules is difficult to implement. To effectively control the façade along the street, it is necessary to have operability regulations such as the type of building type along the street. Article 58 of the "Implementation Rules for the Urban Planning Regulations of Nanjing” (2007) stipulates that 'the setting of outdoor advertising and signage facilities should be 
properly positioned, proportioned, and the shape, style and scale are harmonious with the surrounding environment and architecture.' This regulation still lacks quantitative indicators of operability, and lacks quantitative regulations on the size and location of facilities such as billboards.

\section{Conclusion}

Among the regulations related to the material form of urban streetscapes in China, the compulsory provisions directly related to land use, plot indicators, and architectural layout are directly related to the regulation of land development, building location and building group space distance. It is closely related to the urban street profile and will eventually affect the quality of the urban material environment. Urban style, architectural style, and advertising-oriented provisions are the most important requirements for the control of street profile characteristics. However, due to the lack of operational indicators, the implementation is not strong. China's current relevant regulations as a basis for design and construction have a direct or indirect related effect on the characteristics of urban street profiles, but the form problem is not the result of direct direct regulation, but also the implementation of solving functional problems such as urban health and safety. As a result of the incident, the current urban material form has no regulations as a direct basis. Therefore, based on the perspective of urban form, China will be subject to the preparation, revision and improvement of relevant laws and regulations without affecting urban functions.

\section{Acknowledgements}

Fund support: Ningxia Natural Science Foundation project funding (fund number: 2018AAC03042);

National Natural Science Foundation of China (No.51868064);

\section{References}

[1] Dingwowo. Research on Urban Spatial Form and Its Modeling Control in Nanjing [Z]. Nanjing: Nanjing University, 2007

[2] Interim Provisions on the Management of Urban Construction Planning in Nanjing [Z].1987-01-01

[3] Guaralda M. Form-based planning and liveable urban environments [J]. Urban Morphology (2014) 18(2): 157-62

[4] Emily Talen. City Rules: How Regulations Affect Urban Form [M]. London: Island Press, 2011

[5] Sun Hui, Liang Jiang. The Significance of "Street Profile” [C]. 2005 Urban Planning Annual Conference Proceedings: Detailed Planning, 2005: 937-944

[6] Karl S. Kropf. The Definition of Built Form in Urban Morphology [D]. University of Birmingham, 1993: 505-506

[7] Ding Wowo, Liu Wei, Leng Tian. Foundation of Architectural Design [M]. Beijing: China Building Industry Press, 2014: 95

[8] Marshall S. Urban Coding and Planning [C]. London and New York: Routledge, Taylor \& Francis Group, 2011: 227-235

[9] Gauthier P. Mapping urban morphology: a classification scheme for interpreting contributions to the study of urban form [J]. Urban Morphology, 2006, 10(1): 41-50

[10] Nanjing City Planning Regulations Implementation Rules [Z].2007-04-25

[11] Nanjing City Planning Regulations [Z].1990-08-15 
[12] Nanjing Urban and Rural Planning Regulations [Z].2012-12-01

[13] Jiangsu Province Controlled Detailed Planning Guidelines [Z].2012-01

[14] Jiangsu Province Urban Planning Management Technical Regulations [Z].2012-05-01

[15] Jiangsu Province Urban and Rural Planning Regulations [Z].2010-07-01

[16] Urban Greening Regulations of the People's Republic of China [Z].1992-06-22

[17] People's Republic of China Urban and Rural Planning Law [Z].2008-01-01

[18] Land Administration Law of the People's Republic of China [Z].1999-01-01

[19] People's Republic of China Advertising Law [Z].1995-02-01

[20] Planning and Design Specification for 36 Urban Residential Areas (GB50180-93) [Z].2002-04-01 